\title{
The Ottoman-Jewish Family: General Characteristics
}

\section{Yaron Ben-Naeh}

The Bernard Cherrick Chair in the History of the Jewish People, History of the Jewish People \& Contemporary Jewry Department, Misgav Yerushalayim Research Institute, The Hebrew University, Jerusalem, Israel

Email:yaronbn@mail.huji.ac.il

How to cite this paper: Ben-Naeh, Y. (2017) The Ottoman-Jewish Family: General Characteristics. Open Journal of Social Sciences, 5, 25-45.

http://dx.doi.org/10.4236/jss.2017.51003

Received: November 9, 2016

Accepted: January 3, 2017

Published: January 6, 2017

Copyright (C) 2017 by author and Scientific Research Publishing Inc. This work is licensed under the Creative Commons Attribution International License (CC BY 4.0).

http://creativecommons.org/licenses/by/4.0/

\begin{abstract}
Matters concerning the Jewish family in the Ottoman Empire are very revealing about Ottoman lives and the Ottoman mentality and folklore. We are still lacking a comprehensive research on it, and this is in a way an introduction to this topic. Up until the nineteenth century, the Ottoman-Jewish family was a traditional body shaped by two factors: the inner Jewish one, and that of the surrounding Muslim society, its şari a law, customary law, norms, and values. Jews were acculturated in Ottoman society, and that took many forms, some of which were the nature of the patriarchal family, its folklore, its values, and the mechanisms which dictated its life. The patriarchal system dictated much -from patterns of dwelling to decision making and wills. The social standing and the economic situation were also an important factor in shaping its character, as social norms were much stricter in relation to the middle and upper classes. The family had formal and informal functions, which included continuation of Jewish life and socialization. Procreation and bringing up male children who bore their ancestors' names were highly considered values. The gendered society in which they lived destined different roles for men and women and demanded different requirements-even different values-from each. Men and women lived their lives in parallel, almost separated, spheres. Women were subjected to various restrictions, most of which stemmed from their menacing sexuality. Notwithstanding the basic scheme of power relations, we now know that women had much more power and much more freedom than was formerly believed. We know very little about feelingsbetween husband and wife, between parents and their children, between a first wife and the second-but the sources allow us a glimpse into this world.
\end{abstract}

\section{Keywords}

Jewish Family, Ottoman Jewry, Ottoman Society, Sociology, Acculturation, Patriarchal Family, Gender, Women, Male Off-Spring, Social Status, Honor, 
Moral Codes, Islamic Law, Jewish Law, Urban Life, Marriage, Dowry,

Divorce, Widowhood, Fertility, Children, Love

\section{Introduction}

This article wishes to offer for the first time a panoramic historical view of the Ottoman Jewish family as a social unit with well defined rules that correlated with what was customary in the Muslim society. Such an overview which relates mostly to the Jews in the European Provinces of the Ottoman Empire, western Anatolia and parts of the Levant during the sixteenth to the eighteenth centuries was until now a desiderata.

In the past two decades, Ottoman historiography has been enriched by studies of the Muslim family and Muslim women in the Ottoman Empire, in general, and in Syria-Palestine in particular. Noteworthy are monographs and articles dealing with Syria-Palestine [1]-[6], Egypt [7] [8], and Syria; fewer studies focus on Anatolian urban centers [9] [10].

These studies, as well as many others, examine new subjects or re-examine widely accepted myths and assumptions. Among the topics discussed are polygamy, marriage of close relatives, the importance attached to blood ties, the existence of female networks, the role of women in society and economy (as well as owning and managing property), social control of female sexuality, the status of women, and more. The Ottoman Jewish family is still awaiting a monograph which I intend to write. This article is, in a way, an introduction to it, based on lengthy research and some articles which I authored and are related to that subject. I relate to the pre-modern period, that is, the sixteenth to the eighteenth centuries, and no later than the 1830s. Much has been written in an idyllic and even apologetic manner, and many myths about the Jewish family are still considered true. My intention in this study is to present an updated, even if partial, portrait [11] [12].

The Ottoman Jewish family was based on both Jewish law (halakhah) as it has evolved along the ages, especially in the Iberian Peninsula, and culminated in the canonic compilation called Shulhan Arukh, published in the mid-sixteenthcentury, as well as on the forms, traditions, and customs that it absorbed or loaned from the surrounding society. As Jews were well acculturated in their surroundings, it is no wonder that Muslim society influenced Jewish family structure, the roles of its members, and relations among them. This was either a result of voluntary reception of external influence or of the enforcement of the șari a law upon Jewish men and women who applied to the Muslim court to confirm their marriage, force their partner to agree to a divorce, demand alimony, or compel their mate to live at home. Jews exploited the fact that divorce proceedings in Muslim courts were much simpler and speedier than those of the halakhah, which is purposely cumbersome to prevent light-headed breaking up of families. There is evidence of frequent application to the şari a court for a 
divorce. Jews were well integrated in the wider socio-cultural milieu of urban life in Ottoman cities and moreover in the characteristic age-old culture of the eastern Mediterranean. Study of what typified the majority society can help us ascertain the characteristics of the Jewish family and society [13] [14].

For the Ottoman state (excluding the sultan's slaves), the family was the primary social group and also the basic unit for taxation purposes. Ideals, values, customs, norms, and economic factors shaped the character and structure of the family, which in turn bore the values of society and imparted them to its members. From the moment of his birth, an individual's social status was that of his family which, in addition to supplying his physical personal needs, did everything in its power to educate him and shape his personality in the light of society's values. As such, the family served as a primary socializing and cultural agent. This is all the more true of the wife and mother, who rarely left the confines of her home and raised the children. The Jewish community and the congregation did its best to protect the family cell through various ordinances that regulated marriage, division of property, and other matters in order to assure its stability.

The nuclear family (it seems that a nuclear family was the norm) and the clan were factors in enhancing social status and a significant element in daily life, as part of the wider social fabric, and the primary source of help and support. This did not cease after a person's marriage - and in some families also after death, as he or she would be buried in the family plot in the cemetery. Family events and ceremonies gave tangible expression to a sense of belonging and unity, although in many cases there were quarrels and disputations. Often, members of a family also maintained business relations among themselves. The extended family and its familial ties played an important role-for good or for bad-in determining a person's social and economic status: the entire family basked in the limelight of a respected member but suffered disrepute and dishonor if he was disgraced or degraded. The constant maintenance of the family's honor and respectability was an important part of an individual's life, because honor was a significant element in establishing social status and a valuable factor in all relationships and contacts, from arrangement of a marriage to business connections. Family honor bore much weight in arranging marriages [15].

The patriarchal character of the Jewish family was reflected in several manners. The first was male dominance: the father (or the eldest son, if the father was no longer alive) was responsible for the entire family; children were subordinate to the father until they reached maturity and, together with the women of the house, were legally under the protection and responsibility of the male head of the household. Up until modernity, it was he who decided who his daughters would marry and on the appointed day handed them over to their bridegroom's family. Except for rare exceptions, it was always a grown-up male who represented the family before government agencies, including the kadis court. Disposition of inheritance was the province of men, who also determined the personal and religious status of their offspring. Members of the family were expected to treat the father with respect, and among Jews whose provenance was the Iberian 
Peninsula it was customary for them to address him as "señor" [16] [17]. Even when they were grownups, children were obligated to honor and respect their parents, showing this through accepted forms of etiquette and gestures, such as kissing their hand or requesting their blessing.

The residential pattern was patrimonial, as long as it could be afforded. A young couple usually lived in the home of the husband's parents during the first years after marriage until achieving economic independence, and sometimes until the father passed away and his property was divided among his heirs, who would share a courthouse or an apartment. The custom of marrying minors, or at least at a young age, reinforced this pattern, which was most compatible with the patriarchal system. Obviously, this was dependent on the financial standing of the bridegroom's parents. "Mesafranca"-living quarters in the home of the bridegroom's parents-was a common stipulation set during marriage negotiations, especially among families of the middle and upper classes.

In addition to the core family (father, mother, and children), the household included relatives (parents, stepbrothers and sisters, solitary family members) as well as servants and slaves, all bowing to the will of the senior male member. It may be that the "patrimonialism" characteristic of the sultan's palace and the great homes of high officials in the realm influenced the upper classes, including the economic elites of the Jewish communities [18] [19].

Much importance was attached to the birth of male sons who would bear the family surname, at times together with the given name of their grandfather, both expressions of honor and family continuity. In some congregations in Salonika, the father's given name became the family surname while in the Arab provinces the parents were called after their sons, as was customary among their Muslim neighbors. Childless rabbinic authors at times gave their literary works titles that would commemorate themselves, instead of children that were never born or did not survive.

There was also an economic motive for preference of male progeny: sons often joined the father's business or occupation and helped him, while daughters remained at home, contributing little to the family income. Furthermore, marrying off a daughter meant preparing a bridal dowry and detracting a significant sum from the family assets, almost without any recompense. In addition, safeguarding a girl's virginity and a spotless name involved no little bother. No wonder that there were people who considered the birth of a girl to be a curse.

It was so important to have a son that the rabbis might permit a man to wed a second wife if his first did not give birth to a boy within ten years. Jews also turned to the supernatural in this matter as is attested by the large number of books of magic remedies and incantations that have survived from this period, containing prescriptions to ensure the birth of a boy and texts of vows and talismans to protect the mother and her child. On the eve of a boy's circumcision, a special ceremony was conducted to protect the baby from any harm: Torah scholars were invited to the home, where they read and studied passages from the Bible and the Zohar, recited the blessings over the refreshments they were 
served, and sang liturgical hymns. When girls were born it was usually far less happy event that a male baby. The father was sometimes ridiculed, and the family was already worried thinking about the burden that it concerned - financial and even a moral one [20]. However, When a daughter was born, it was customary in certain Jewish circles to also arrange for a ceremonial meal with the participation of a hakham and on that occasion to name the baby ([16], p. 1:105; [17]).

\section{Marriage}

Among Jews, just as in the majority Muslim society ([4], pp. 111-152), it was considered obligatory for every healthy person to marry. Marriage was the common legitimate framework for bringing children into the world and, at least as far as women were concerned, for satisfaction of sexual needs. The family cell, established by the matrimonial tie, was considered a key to social harmony, a foundation stone of society, and an important barrier against social disorder. Yet, prostitution and concubinage existed, and men had children by other women, including slave-women [21]. These children were legitimate if the father acknowledged his parenthood.

Bachelorhood as a permanent state of affairs, whether voluntary or by the force of circumstances, was frowned upon. Unmarried men and women were thought to be of questionable morality, deviating from the social order and presenting a threat to the integrity of existing family cells. A question to R. Hayyim Kafussi, from early seventeenth-century Cairo, relates to a man who repeatedly told community members that he does not wish nor can he marry a wife. The question shows how people intervened in the lives of others, a far cry from the modern Western mentality.

Among the communities in the Ottoman Empire, that of Jerusalem was unique in the measures it took to assure strict moral standards and maintain its image as a holy community, and therefore forbade bachelors aged twenty to sixty from living within the city so as to prevent illicit relations, or any contact that might lead to a sexual encounter [22].

Bachelors were exceptionally numerous in cities that attracted emigrants and persons seeking work. Bachelorhood was on the whole a temporary state of affairs, especially with men who delayed marriage until they could save up the money for a wedding and the many expenses it entailed. Women remained single due to poverty, a serious deformity, or a blemish on their family.

The bridal dowry (ashugar in Judeo-Spanish) was an important and vital component in marriage arrangements between families. Since the lack of a dowry could prevent a girl's marriage, benevolent societies were formed to help marry off daughters of the members or poor orphan girls by providing them with dowries. These sums were so significant, together with a desire to exaggerate and flaunt wealth, that some communities felt obliged to enact regulations that would limit the sums, and also levied taxes on them. The value of the dowry, which included money, jewelry, and clothing "conforming to the honor" of the bride's father, was of two-fold importance: on the one hand it reflected or at least 
hinted to the father's socio-economic status, while on the other it enabled the young husband to establish a commercial enterprise and support his wife in the manner to which she had been accustomed. The amount of the dowry was also a deterrent against speedy divorce and provided the wife with a degree of economic security in the event that she would be divorced or widowed. The fact that she was entitled to these sums to some extent balanced the status of the wife vis-à-vis her husband, his family, and the future inheritors. As long as she did not redeem the sum due to her, the inheritors continued to be responsible for the welfare of the widow [23] [24].

Even though the halakhah overtly places the wife in an inferior position, it also defends her elementary rights, in addition to the provision of her legitimate basic needs. Jewish law forbids beating her, allows her to demand a divorce, and in the case of divorce or the death of her husband ensures her the sum inscribed in her marriage contract [25]. The matrimonial bond is conceived as a contractual arrangement between two persons of two sexes (as it is in Islam), the difference in gender accounting for legal decisions handed down over the centuries in relation to family matters. Conditions of time and place-perhaps even more extremely-defined certain gendered behavioral norms. A man had one set of rights and obligations, while a woman had a different one. The husband had to treat his wife fairly, conduct reasonably frequent sexual relations with her, and properly provide for her livelihood, supplying food, clothes, and her other needs (e.g., hamam fee) in a manner becoming her status from the day of marriage until death, or until they parted by divorce. The wife was to obey her husband, reside in his home, and agree to live together with other members of the family, even with her husband's mistress. She was responsible for the upkeep of the home. If the husband decided to move to another city, she was obligated to accompany him, though this was subject to some conditions and limitations.

Matrimony was not only a matter of a supposedly lifelong relationship between two individuals but also, even primarily, one between families. The couple's relatives, especially the father and brothers of the bride, exploited this relationship to further their family objectives and as a means of maintaining or enhancing their own social status and wealth, all this in accordance with the accepted norms of the time and subject to confirmation by the congregational leadership. While taking care to contract marriage with someone of the same socioeconomic status was characteristic of Ottoman Jewish society, it continued an older tradition among elite circles. However, some influences of living within the Ottoman majority society are also evident, such as adoption of the custom to free a female slave and marry her or wed her to a member of the family or a friend of her former owner [21].

Relations between the prospective bride and groom did not arise spontaneously and out of love [26]. They were generally the result of family initiative to arrange for an engagement and marriage at as early an age as possible. Marriage was a result of matchmaking, at least among the middle and upper classes, which would not allow clandestine a bond. Various mechanisms were at work to assure 
the best possible match: on the one hand, social norms determined who was a suitable partner, and on the other hand, regulations and ordinances of the community that obligated the presence of some congregational officeholder, usually the rabbi (hakham), at the wedding ceremony and prohibited secret and farce marriages (kiddusheiseter, kiddusheitzhok). These ordinances were intended to prevent unsuitable matches, especially marrying a woman to a stranger who might also have a wife in another city, or to someone of lower social standing than herself. These efforts were not always successful: the absence of coercive and punitive power was a serious obstacle to enforcement of ethical regulations and congregational ordinances relating to marriage. Many scoundrels applied to the şari a court or simply fled to another city, where they began life anew. Rabbis did their best to prevent such cases, and when they learned details about transgressors who had fled elsewhere they would inform their colleagues in the other city who could then take measures against these men [27]. Often, the match was the result of feminine initiative and a lengthy search for a fitting partner that entailed many checks carried out by women through the communication networks they maintained. After the suitable male or female partner was found, the matchmaker began his efforts and through his mediation men from both families finalized the conditions, at last publicly bringing the match to fruition.

What we know of the search for an ideal marriage partner also reveals the ideals of Jewish society. In the sixteenth through the eighteenth centuries, wealth and lineage were what was most highly valued. As for the partners themselves, the man was expected to have an education and the ability to earn a living, while the woman should be healthy and fecund. Climbing the social ladder through marriage was almost impossible for the lower classes, unless they made up for their inferiority with some other advantage: erudition for men and, perhaps, beauty for women. In the absence of anything more attractive, the major assets of unmarried women were a good reputation, virginity, health and potential fertility, and young age. It seems that a young virgin was a much-sought status symbol, so virginity had an economic value and was an advantage, but not obligatory. As it was difficult to maintain a girl's virginity and good reputation, it was best to marry her off as early as possible. As women earned less than men, this made it all the more compelling for poor girls to marry an elderly man, a widower, or a cripple to evade dependence upon relatives, spinsterhood, and a life marked by solitude and want. The unmarried state was especially difficult for a woman, who was expected to remain indoors and mostly needed a husband to support her; marriage was thus important for her security and social standing.

The preference for marriage between relatives, especially cousins or of an uncle with a niece, customary among Muslims in countries around the Mediterranean, was also common among Jews. This resulted from the patriarchal family structure and had clear social and cultural advantages: acquaintance between the families of the destined partners, while the dowry money would remain as part of the family assets. This may explain why such marriages were more frequent 
among the social and economic elites who were concerned with maintaining a closed social group, in addition to their privileges and property. There were those who believed that marriage within the family would prevent conflict and separation ([28]; [4], pp. 132-140). Another characteristic-marriage of minors or adolescents-was apparently more frequent among wealthy families. For them there was no economic or social obstacle to an early marriage because the young couple's needs would be taken care of, and they generally lived in the home of the groom's father. This does not rule out cases in which the husband was older than the wife, and even though the act of betrothal (kiddushin) during the wedding ceremony was conducted, the bridegroom would wait until his wife matured sexually before consummating the marriage [29] [30] (As for Muslim family life in Palestine see [31]). This act, that included a ceremony and wearing the betrothal ring, signified the end of a lengthy process [32] [33].

\section{Composition and Size of the Family}

On the whole, the Jewish family in the metropolitan centers of the Ottoman Empire was monogamous. The impression is that polygamy was less frequent during the seventeenth century, and even then more prevalent in the Arab provinces than in Anatolia and the Balkans. This matches the consensus among scholars today that bigamy was infrequent and to a great extent conditional upon the economic ability to support two wives or maintain two households ([24], pp. 316-317; [34] [35] [36] [37]).

Whether the ban on bigamy enacted by R. Gershom ben Yehudah "Me'or haGolah" (10th-11th centuries) should be enforced was an issue never unequivocally decided by the rabbinical authorities in Jewish communities in Islamic countries. The halakhic basis for monogamy in these lands rested on the Sephardic custom of having the bridegroom swear during the wedding ceremony that he would not take another wife. The recommendation of the decisors was not to marry a second woman other than in exceptional cases, for instance if the first wife became an invalid, took seriously ill, or had been unable to give birth for at least a decade. In this last case the first wife could not oppose her husband's step, and if she refused to receive a second wife in her home could demand a divorce or, for the rest of her life, remain an agunah (pl. agunot, a married woman separated from her husband without a divorce, who could not remarry), with a serious blow to her rights.

It is difficult to conclude what was the size of an average Jewish urban family unit during the sixteenth, seventeenth and eighteenth centuries-preceding the demographic transition so identified with modernity and modern age, and whether it differed from that of its non-Jewish neighbors. What is clear is that statistics differ from one area to another and for different periods of time [38] [39] [40] [41].

In the absence of information that would point to planned families and the use of any form of contraception, it is almost certain that every wife became pregnant many times during her period of fertility. All this notwithstanding, the 
number of children who reached maturity was not great: many pregnancies ended in miscarriage or a stillborn child, while many young children died from an illness or the frequent plagues. It therefore seems that it would not be an exaggeration to say that only two or three of a family reached maturity, though Hebrew sources do mention families with four or five grownup children. A second marriage resulted in the husband fathering more progeny. The number of children who survived was greater in wealthy families since they could provide better conditions, including superior food and access to physicians.

\section{Widowhood, Divorce, and Remarriage}

The primary factor leading to the breaking up of the family cell was the early demise of one of the partners. This often happened a short while after marriage, at times even before it was consummated or children born. In such cases there were generally disagreements about how the couple's assets and wedding gifts should be divided and over the return of the dowry.

In some cases both partners sought a divorce, but most frequently the initiative came from the husband. More than likely, this step was adopted only after the family's efforts failed to bring about conciliation between husband and wife and the financial loss that a divorce would entail had been taken into consideration. The most frequent pretexts were physical or medical: unwillingness or inability to conduct sexual relations, infertility, and deformities or chronic maladies such as blindness, epilepsy, or mental disease. Less frequent reasons for divorce were those connected with the personality of the couple and the relations between them, which is interesting in itself, unless the sources do not reveal all the motivations. Other reasons for a divorce might be the husband's wish to take a second wife, deplorable manners, promiscuity, violence, and the wife's refusal to follow her husband to another city or to emigrate with him to the Holy Land.

After negotiations inside the family circle failed and it became clear that the couple could not settle their disagreements, they applied to the rabbinical court which, in turn, did not opt for speedy divorce, at first trying to bring about conciliation between the two. Though the halakhah forbade divorcing a woman without her agreement, there were ways to "convince" her: the court could deprive her of the right to the sum recorded in her wedding contract or permit the husband to take another wife, leaving the first in the state of being an agunah. It was much more difficult to force an obstinate husband to agree to a divorce. The judges had to maneuver between the prohibition against forcing the husband to give a divorce and the wife's demand to bring an end to the marriage, while their authority and even their power to enforce any verdict in this matter were limited. At times we hear of a husband who adopted the Muslim formula of talaktlata, or that a woman went to the kadi and requested a divorce, using the appropriate argumentation which the şari as demands in order to rid herself of her husband. Though it is difficult to assess the extent of divorce rate among Jews, it certainly was not rare and the status of divorcé and divorcée did not bear a stigma ([24], pp. 314-316; [36], pp. 149-161). In the majority of cases the divorcée 
returned to her parents' home or took up residence with other relatives.

The condition of agunot was much more difficult. A woman whose husband had disappeared without leaving a trace could not remarry as long as there was no proof that her husband died. The rabbis were torn between their obligation to follow the severe religious criteria concerning verification of death and their wish to ease the condition of agunot. This inclination was not only the result of pity for the woman but also-perhaps primarily-fear lest she remarry illegally, become promiscuous, or convert.

In both Muslim and Jewish society a second or third marriage was fairly prevalent and it seems that being a widow or a divorcée was not considered a serious defect unless the woman had already been widowed three times and was thought to be "lethal" ([36], pp. 161-162). It is interesting to note that according to the British traveler Paul Rycaut, among the Greeks a thrice-widowed man was forbidden to marry a fourth time [42].

Two major factors influenced the prospects of a woman to remarry: her financial condition and her fecundity. A wealthy woman could expect to marry again within a short period of time and from a good bargaining position, while the chances of a poor woman were far worse, especially if she was old and could no longer give birth. A man who wanted to remarry and had children from a previous marriage was in a better position than a widow with children. In addition to the difficulty of raising another's children there was the economic aspect: not many could bear the financial burden involved. Mothers who wished to remarry made every effort to keep their children in their new household, and even made various economic arrangements to that end. Thus, we read of a case in which a widow stipulated, as part of the agreement contracted for her second marriage, that her new husband allow her to continue to raise her son. She promised to cover the costs of his upkeep and threatened that should the husband refuse, she would live separately from him until the son was married [43]. Mothers were not always successful and at times were forced to place the orphans under the aegis of a relative-a grandfather, uncle, or grownup brothers. In the absence of close relatives, the worse the economic condition of the extended family, the smaller the prospects that relatives would take custody of them, and there were indeed cases in which they were practically abandoned to their fate. When a man remarried, he was dictating the conditions, but at times his wife's relatives demanded possession of the orphans, arguing that they should be raised by relatives who would do so with love, not by the father and his new wife ([24], pp. 330-331; [44]).

\section{Family Life}

Birth and death were the poles around which family life revolved and as long as a woman was able, she gave birth almost every year or year and a half. Death due to pregnancy complications, miscarriage or hard labor was not rare, and these years were the most dangerous for women. Upon menopause, around the age of forty, she was considered an old woman [45], which meant, among other things, 
that she lost her sexual attractiveness and was less menacing. Birthdays, even when a son reached the age of thirteen, were not accorded much importance, and often not even exactly known. The birth of sons and their circumcision, as well as marriages, were the events celebrated with much ceremony because of their social importance-they signified continuity of the family or a tie with another family, one that in addition to the social and economic advantages which could emerge from the relationship was also expected to produce progeny.

Death was always near at hand, part of the experience of daily life. Babies, children, and young people died of diseases or home accidents, itinerant merchants and travelers passed away or were murdered while traveling the roads or the seas, and elderly people died a natural death. Seasonal plagues caused deaths among young and old, especially in the summer months. Every few years there were serious outbreaks of epidemics that claimed many victims. At times, entire families were wiped out within days. The sources also make rare mention of homicides and suicides.

Most people died at home, surrounded by their family who took care of their needs. Those who were poor or lonely were attended by members of the BikkurHolim [=visiting the sick] Society, all volunteers, who primarily looked after needy ill people, but also tended others. When the end was drawing near, representatives of the HevrahKadisha [=holy society] were summoned. They kept a vigil near the bed of the dying person, recited with him the confession before death, and were sometimes witness to his last will and testament. After he passed away, they conducted the ritual purification of the body and dressed it in the shrouds the deceased had prepared during his lifetime. Poor people received shrouds from the burial society or from a special fund established for this purpose. In the neighborhood in which the deceased resided, it was customary to pour out water that had been standing uncovered at the time of death. The body was placed in a coffin and arrangements for the funeral were made as quickly as possible, as Jewish law requires an immediate burial.

As far as we know, only men participated in the funeral procession. Perhaps the women walked further behind or just watched the procession from the windows of their homes. Jewish funerals, unlike those of Muslims, were not known for being restrained, and were accompanied by professional women keeners (who were often hired by other religious communities). When the deceased's family returned from the cemetery, they sat down to a special meal, by which mourners are comforted and sustained immediately after the burial. According to custom, the neighbors provided the simple and symbolic dishes: hard boiled eggs, lentils, cheese, and bread. Additional daily meals were provided during the seven days of mourning. The family visited the gravesite on the thirtieth day after the deceased's passing, once again when a year had gone by, and then every year on the anniversary of his or her death. On these occasions, too, gender segregation was the order of the day and members of each sex filled separate roles, acting differently [46]. The relatives also set up a headstone, in accordance with 
their financial condition or the instructions of the deceased in his will. Women dedicated more time and resources to commemoration of the dead, and there is documentation attesting to their frequent visits to the graves of their dear ones.

The congregational leadership treated the deceased of the economic or rabbinic elites differently than it did ordinary members of the congregation. The funeral services for important persons were lengthy, especially those of rabbis, whose coffins were placed in the synagogue in which they served or in other synagogues, where eulogies were delivered accompanied by the chanting of cantors. Many participated in the funeral procession and burial ceremony, and a great number of people-relatives, laymen, and officeholders of the congregation-would come to console the mourners. The fact that outward features such as expensive shrouds, an impressive headstone, large meals, and the like were status symbols encouraged the families of the deceased to expend sums they could not always afford.

The lifestyle of Ottoman cities resulted in the man and wife conducting their lives in different circles. The husband would go out to earn his livelihood from morning until evening, and then spent his leisure time in the company of male friends in the neighborhood coffeehouse, in a tavern, or in semi-religious activity in one or more of the benevolent societies. Members of the wealthy families adopted the conventions and mores of the Ottoman elites regarding strict segregation of the sexes. Wealth also enabled physical segregation within the home: the women and small children slept together in a part of the house (harem) that was set off from the husband's quarters.

The wife spent most of the day in the company of female relatives or neighbors in her home or the common courtyard, together with other women who were not necessarily Jewish. Her responsibilities included supervision of the household, the children's education (only boys attended "school"), preparation of food, housecleaning, and laundry. Many hours were spent cooking - a process that began with bringing water from nearby water fountains, grinding cereals to flour and baking bread, and culminating in the preparation of complex dishes, jams, and all kinds of pastry for festive occasions. Relatively cheap labor and the availability of servants enabled upper-class women to employ female servants who did some or even all of the work, including preparation of kosher cooked food. Thus, wealthy women were free most of the day; European travelers describe them as spending most of their time paying visits or engaging in embroidery, playing and listening to music, smoking, drinking coffee, and consuming fruit and sweets [47].

Women who had to work to support the family tried to engage in some craft at home, not outside it. Shopping was done by men or servants. Opportunities to leave the confines of the home were primarily for visits to the bathhouse. This they did in groups once or twice a week, spending many hours there. The visit to the hamam was accompanied by eating and drinking, music, dancing, and singing. On these occasions they flaunted new clothes and jewelry (a habit that was condemned and even banned from time to time), exchanged news and gossip, 
planned matches for their children, and had a chance to examine at first hand future brides for their sons. In certain cities women would go out together into the fields outside the city and hold picnics there. Another form of female recreation was to go to the cemetery to visit family graves, a custom apparently borrowed from popular Islam. Similarly to the neighbors, women rarely attended prayers in the synagogue, and this generally only during services of the High Holidays.

It is possible that due to difficulties of communication with a husband who was older than themselves, physically remote, and not necessarily loved, wives tended to nurture ties with other women-relatives or neighbors, sometimes even of a different social class. In such friendship they found comfort and support over and above what was provided by the family.

The recreational patterns of Jewish men and women were gendered and similar to those of their neighbors: men spent their few leisure hours in the coffeehouse, the tavern (a manly territory), or the bathhouse, while women paid lengthy visits to the homes of female relatives and friends and, as noted, in joint outings to the hamam, to visit graves in the cemeteries, or to green areas outside the city (again, a habit that was considered by the rabbis as a potential moral risk). Among the amusements of upper-class males were riding horses and indulging in certain types of competitive sport [48]. When they were free from other business, as well as on official state holidays, the Jews, together with the other subjects, could take in diverse street amusements such as puppet plays and lantern shows (karagöz) or performances of acrobats, dancing, and music. Rich dinners organised by those who could afford them provided a convenient opportunity to display one's financial standing and dining together was a means of enhancing interpersonal relations and strengthening loyalty.

Since there is little information about how the Jewish holidays were celebrated, we have to rely to a great extent on descriptions dating from the late Ottoman period set down in writing during the twentieth century (for example, the descriptions provided by Moshe Attias, David Benvenisti, or in the works of Ya'akov Yehoshua (describing Jerusalem), and others). The family spent time together on Saturdays and holidays. The men first attended prayers, after which the entire family ate together and then went out to visit relatives [49].

Relations between husband and wife, and between them and their children, have been the subject of very little research to date, so we have only sparse information about intimacy within the family. Under the influence of Muslim patriarchal society, more importance was placed upon blood ties, and the written sources point to close ties between the father and his extended family. It would seem that despite their apparent importance, marital relations were not the focus of family life and relationships; neither is it clear just how important they were for either the husband or the wife, nor what did love mean and what were its manifestations. Relations between husband and wife were dependent upon their personalities, on whether the wife was able to find favor with her husband's relatives, her ability to bear him sons, and the test of their life together. Even if they 
were forced into a match that was not based on prior acquaintance and emotional attachment, at times there developed a partnership marked by liking, friendship, love, and passion [50]; there are very few mentions in the Hebrew sources of love between husband and wife in its modern romantic form [51].

There are almost no literary expressions of true love, but it is clear that romantic love did exist and was even sought. It appears as a motif in folk songs and proverbs, but there it gives rise to complications and ends tragically. It may be that this was meant to discourage any prospect of love becoming a factor in making matches or in marital life; in fact, some of the sources even rule out the legitimacy of love altogether.

We have more frequent information about tension and disagreement within the family. The responsa literature includes information about oral rebuke and physical violence between husbands and wives. Though there is little written evidence of a husband beating his wife, this was apparently quite common, especially among the lower classes (see the instructive opinion of R. Eliyahuha Cohen who took for granted that a husband beats and curses his wife when he thinks her behavior improper [52]). Similarly cases were recorded in which a violent wife curses her husband and his parents and strikes him or has recourse to others to beat him [12]. Tension between a bride and her mother-in-law was so common that it was often dealt with in the corpus Ladino Ottoman folk songs and found its way into proverbs which consider this to be the obvious state of affairs [53] [54]. The fact that the young couple lived with the husband's parents, at least during the first years of marriage, placed the young bride in a position of inferiority and provoked and even increased the natural tension between her and the mother-in-law, and at times also with her senior sisters-in-law.

\section{The Status of Women}

The male-centered class society in which women lived saw them as a separate social category with its own rights and obligations. And yet, one cannot refer to "the woman" in Ottoman Jewish society because there was no typical model of a woman. The status of married wealthy women was not similar to that of poor women or young girls, Muslim women differed from non-Muslim ones, and women living in the cities from those in the rural areas. Furthermore, the accepted norms in Syrian cities, for example, were not necessarily identical with those in Egypt, the Balkans, or Anatolia. The role and status of women is a topic that recent Ottoman historiography has completely revised, but did not affect the wider discourse on the subject. Studies published since the beginning of the 1990s have to a great extent shattered the Orientalist image of the submissive, passive woman who is isolated, reserved, ignorant, and lazy. This conception, created by Europeans who traveled to the Orient over hundreds of years, was perpetuated in their writings and drawings. Contemporary research has replaced the accepted image with a completely different evaluation of the status of the Ottoman woman within the family and of her involvement in urban life, as reflected primarily in the records of the șari a courts. This goes hand in hand with 
the tendency to see social frameworks, including the family, as less rigid than they were thought to be in the past.

Segregation of the sexes and a patriarchal structure were the most significant aspects of urban society in the eastern Mediterranean basin. These shall now be briefly discussed in relation to the family, economic activity, and legal status.

\subsection{In the Family}

Throughout her lifetime, a woman was almost always under the aegis of men: at first of her father or brothers, then of her husband, and after his death of her son or sons. Men assumed responsibility for her behavior and for ensuring the fulfillment of her obligations vis-à-vis the authorities and the public -whether Jewish or not. However, the view that assumed absolute superiority of the husband in the patriarchal family and complete subordination of the wife is mistaken. It has been replaced today by recognition that there were parallel hierarchies, with each partner having a different set of rights and obligations. Moreover, under certain circumstances older (and wealthy) women could take priority in household and family affairs; for instance, in the interim between the father's death and his son's coming of age the wife, or even the husband's mother, might replace him. Differences in the age and life expectancy of husband and wife made such a situation possible, even if it was not very frequent.

Furthermore, both Ottoman law and the halakhah placed limitations on the power and authority of the husband. Women were aware of this (some more, some less) and when necessary adopted a strategy that seemed suitable to them: they turned to members of the family, to the rabbinical court, or to the şari a court to demand their due or complain about some injustice committed by the husband or his family. There were even cases in which Jewish women applied by themselves to the şari a court, complaining against their husband, even requesting that the court order him to return home or conduct sexual relations with them.

Regarding the discussion about women's status, power or weakness in this society we should add that there is yet another source: oral literature, or the genres which are passed on orally, not only songs and proverbs, but also the personal narratives. Such narratives of Sephardic women of traditional background similar to those related to in the essay, documented in the late twentieth century, convey no wish to rebel against the rules of the traditional world in which they grew up. These women made them flexible, thus proving that a wise and resourceful woman may benefit from tradition by implementing her independence within its boundaries [55].

\subsection{In Economic Life}

Women played a role in the economic life of Ottoman cities. They bought, sold, rented, and leased out property, gave out loans with interest, provided credit, or guaranteed loans, bought and sold merchandise, and more. Lower-class women engaged in production of handicrafts, peddling, and provision of diverse services: 
music, dancing, cosmetic and medical treatments, or as servants. The occupations and economic activity of women changed in accordance with their socioeconomic status, the economic needs of the family, their talents, and norms of the region in which they resided. Their right to private property was recognized in both Jewish and Islamic law. The most common way of accruing property was to inherit it or receive it as a gift, and a woman could keep it even after her marriage and manage it as she saw fit. Ownership of assets such as cash, jewelry, promissory notes, and property, or the ability to earn a living independently, provided the wife with some power en face her husband and a certain amount of independence in running her own affairs (one example is the case of a woman who had her own income and rejected her husband's complaints about the way she spent her money [56]).

\subsection{The Status of Women According to the Law and Social Norms}

Like dhimmis and slaves, women were a category unto themselves, their status in general society being inferior to that of Muslim men. A rigid corpus of law grounded in the şari a shaped the lives of women-including Jewish womenbut there were those who refused to submit and rebelled. A woman had ways and means by which she could get around her inferior status, even if she was unable to revoke it absolutely: turning for help to her family, using a proxy, applying to a court, or petitioning the sultan. Both the general public and Islamic law exhibited a certain flexibility vis-à-vis the system of strict segregation, and women exploited this. Having the right and ability to complain about injustice, cruelty, extortion, or discrimination and to demand their rights granted them some power. Divorcées and widows had more freedom of action than did young girls and married women. All in all, the wealthier and older the woman, the more independent she could be, though a high social standing obligated a woman to more strict observance of the rigid social norms demanding seclusion of women.

\section{Gender Segregation}

A concept that presumed a fundamental difference between the sexes was at the basis of social norms, the halakhah, and Ottoman legislation. For men in the Muslim East, a woman's sexuality was the basic element in the nature of her identity, which was different from and inferior to that of men. Her sexuality was seen as being so seductive as to endanger the social order. The male, in contrast, was conceived as having a perpetual sexual lust for whom every contact with a suitable object of desire-a woman or a boy-bore sexual potentialities. Since the assumption was that a man's sexual drive could not be suppressed, the way to avert the danger was to control the display of feminine sexuality, especially by keeping women out of the public domain. In the cities, a woman was restricted to the area of her home and if she had to leave it was obliged to cover her body with a cloak and don a veil that concealed her identity and facial features ([2], pp. 150-155; [22] [57] [58]). An honorable woman would not go without a cha- 
peron of some sort.

Seclusion of women and protecting their chastity were social norms reinforced by the state, by religious law, and by traditional social norms. In contrast to a man, whose sexual lust arose when he matured, a woman was considered as possessing sexuality and desires only from the moment she married and had been introduced to marital relations. Thus, restrictions relating to modesty and strict social supervision were the lot of the woman particularly after she married, which in any case generally happened when she reached puberty. As already noted, responsibility for the education of a young girl and safeguarding her chastity were placed upon her father, and after marriage became the responsibility of her husband. The head of the family was supposed to control the sexuality of the members of his household, thus ensuring his own exclusive rights as husband and protecting his manly honor ([57], p. 25) (For the husband's duty to prevent his wife from setting foot outside the home, see, for example, the following injunction: "Keep an eye on your wife lest she go out to the tavern and, it goes without saying, for walks in orchards and in the company of women who befoul their mouths" ([52], p. 52d). Jews adopted this approach from the majority society. As with other Jewish values, in this case too an accepted norm of Muslim society reinforced an existing Jewish value, giving it new form: rabbis were quick to adopt this manner of contending with the danger to social order and morals posed by female sexuality. In ordinances, sermons, and lectures on moral behavior they praised the strict Muslim conventions relating to female modesty. Women were called upon to hide their presence by limiting to a minimum their movements in public areas and covering most of their body. These demands were inculcated through formal and informal education, and enforced by means of congregaional or communal regulations.

A constant accusation runs through the rabbinical literature: women flaunt their sexuality and purposely arouse lust in men. There were even those who were aware of Muslim public opinion in this matter and expressed their concern about its possible reaction to sexual permissiveness among the Jews that might range from anger, which could lead to physical danger, to mockery and derision of Judaism that entailed defamation of the name of God. It would seem that in comparison with other, especially Muslim, urban women, Jewish women did enjoy greater independence. It could be that the myth fostered by European travelers about the great degree of freedom of movement and the sexual promiscuity of Jewish and Christian women is a distortion resulting from what they saw in the great, bustling centers of the cities they visited. In small, provincial cities they probably encountered a different reality. Perhaps they purposefully exaggerated in order to emphasize the contrast between Islam and ChristianWestern civilization.

\section{Conclusion}

This article is a longitudinal survey of the Ottoman Jewish family in the premodern era-from the sixteenth century until the 1830 s reforms. While previous 
studies have examined some facets of the Jewish family in specific areas of the Ottoman Empire, this is the first to discuss the Empire as a whole.

We analyzed the characteristics of the basic social unit, the family, among a definite group - that of the Ottoman Jews. Jewish Ottoman world was not only governed by the same regime, and used one language in most of its provinces, but was also "united" under the halakhic dominance of the Sephardi scholars and the sixteenth century opus magnum "Shulhan Arukh" that dictated their lives. Up until the nineteenth century, the Ottoman-Jewish family was a traditional body shaped by two factors: the inner Jewish one, continuing the Iberian Jewish law and customs as well as some of the local Romaniot traditions, and that of the surrounding Muslim society, its şari a law, customary law, norms, and values. Living in an urban environment and being open to influences, Jews were acculturated in Ottoman society. This took many forms, some of which were the nature of the patriarchal family, its values, and the mechanisms which dictated its life both in regular times and under crisis. Social standing and the economic situation were also an important factor, as social norms were much stricter in relation to the middle and upper classes.

The family had formal and informal functions, which included continuation of Jewish life and socialization. Procreation and bringing up male children who bore their ancestors' names were highly considered values. The gendered society in which they lived destined different roles for men and women and demanded different requirements-even different values-from each. Men and women lived their lives in parallel, almost separated, spheres. We know very little about feelings-between husband and wife (or before the wedding, love for example), between parents and their children, between a first wife and the second-but the sources allow us a glimpse into this world. Women were subjected to various restrictions, most of which stemmed from their menacing sexuality. The patriarchal system dictated much-from patterns of dwelling to decision making and wills [59]. Notwithstanding the basic scheme of power relations, we now know that women had much more power and much more freedom than was formerly believed. In the future I intend to broaden this fascinating research, which in a way is also very revealing about Ottoman lives and the Ottoman mentality.

\section{References $^{1}$}

[1] Zeevi, D. (1995) Women in 17th-Century Jerusalem: Western and Indigenous Perspectives. International Journal of Middle East Studies, 27, 157-173. https://doi.org/10.1017/s0020743800061869

[2] Tucker, J.E. (1998) In the House of the Law: Gender and Islamic Law in Ottoman Syria and Palestine. University of California Press, Berkeley.

[3] Marcus, A. (1989) The Middle East on the Eve of Modernity. Columbia University Press, New York.

[4] Meriwether, M.L. (1999) The Kin Who Count: Family and Society in Ottoman Aleppo 1770-1840. University of Texas Press, Austin.

${ }^{1}$ The bibliography is a very seminal and short bibliography, due to the system of citing and lack of space. There are much more primary sources and research literature. I intend to write a book on the subject. 
[5] Establet, C. and Pascual, J.-P. (1994) Familles et fortunes à Damas: 450 foyers damascains en 1700. Institut Français de Damas, Damascus. https://doi.org/10.4000/books.ifpo.7504

[6] Establet, C. and Pascual, J.-P. (1995) Famille et Démographie à Damasautour de 1700: Quelquesdonnées nouvelle. In: Panzac, D., Ed., Histoire Économique et Sociale de l Empire ottoman et de la Turquie (1326-1960), Peeters, Paris, 427-445.

[7] Hanna, N. (1995) Marriage and the Family in 17th-Century Cairo. In: Panzac, D., Ed., Histoire Économique et Sociale de PEmpire ottoman et de la Turquie (1326-1960), Peeters, Paris, 349-358.

[8] Sayyid-Marsot, A.L. (1995) Women and Men in Late Eighteenth-Century Egypt. University of Texas Press, Austin.

[9] Jennings, R.C. (1999) Studies on Ottoman Social History in the Sixteenth and Seventeenth Centuries: Women, Zimmis, and Sharia Courts in Kayseri, Cyprus, and Trabazon. Isis, Istanbul.

[10] Gerber, H. (1989) Anthropology and Family History: The Ottoman and Turkish Families. Journal of Family History, 14, 409-421.

https://doi.org/10.1177/036319908901400407

[11] Ben-Naeh, Y. (2008) An Adultery Scandal in Istanbul: Jewish Daily Life in an Ottoman City as Mirrored in the Responsa Literature. East and Maghreb, 8, 37-55. (In Hebrew)

[12] Ben-Naeh, Y. (2014) Dangerous Liaisons in Castoria. El Prezente, 7, 27-41.

[13] Rozen, M. (2002) A History of the Jewish Community in Istanbul: The Formative Years, 1453-1566. Brill, Leiden, 99-196.

[14] Westreich, E, (2002) Transitions in the Legal Status of the Wife in Jewish Law: A Journey among Traditions. Magnes Press, Jerusalem. (In Hebrew)

[15] Ben-Naeh, Y. (2005) Honor and Its Meaning among Ottoman Jews. Jewish Social Studies, 11, 19-50. https://doi.org/10.2979/JSS.2005.11.2.19

[16] Galanté, A. (1985-1986) Histoire des Juifs d'Anatolie. Isis, Istanbul.

[17] Molho, M. (1947) Birth and Childhood. Edot, 2, 255-269. (In Hebrew)

[18] Kandiyoti, D. (1992) Islam and Patriarchy: A Comparative Study. In: Keddie, N.R. and Baron, B., Eds., Women in Middle Eastern History. Shifting Boundaries in Sex and Gender, Yale University Press, New Haven, 23-42.

[19] Findley, C.V. (1980) Patrimonial Household Organization and Factional Activity in the Ottoman Ruling Class: A Reassessment. In: Okyar, O. and Inalcik, H., Eds., Turkiyenin Sosyalve Ekonomik Tarihi = Social and Economic History of Turkey (1071-1920), Meteksan, Ankara, 227-235.

[20] Palachi, H. (1874) Tokhahat Hayyim, III. Izmir, 128a.

[21] Ben-Naeh, Y. (2006) Blond, Tall, with Honey-Colored Eyes: Jewish Ownership of Slaves in the Ottoman Empire. Jewish History, 20, 315-332.

https://doi.org/10.1007/s10835-006-9018-Z

[22] Ben-Naeh, Y. (2006) Feminine Gender and Its Restrictions in the Ethical Regulations of Ottoman Jewry. Pe'amim, 105-106, 127-149. (In Hebrew)

[23] Glazer, M, (1982) The Dowry as a Capital Accumulation among the Sephardic Jews of Istanbul, Turkey. In: Deshen, S. and Zenner, W.P., Eds., Jewish Societies in the Middle East. Community, Culture, and Authority, University Press of America, Lanham, 299-309.

[24] Bornstein-Makovetsky, L. (1998) The Jewish Family in Istanbul in the 18th and 19th Centuries as an Economic Unit. In: Bartal, I. and Gafni, I., Eds., Sexuality and the 
Family in History: Collected Essays, Zalman Shazar Center, Jerusalem, 317-327. (In Hebrew)

[25] Katz, J. (1984) Levirate Marriage (Yibbum) and Halizahin Post-Talmudic Times. In: Katz, J., Ed., Halakhah and Kabbalah: Studies in the History of Jewish Religion, Its Various Faces, and Social Relevance, Jerusalem, Magnes Press, Jerusalem, 127-174, esp. 161-174. (In Hebrew)

[26] Ben-Naeh, Y. (2015) Old Sentiments, New Times: Love as a Factor in Marital Connection among Ottoman Jews. El Prezente, 8-9, 61-83. (In Hebrew)

[27] Responsa and Epistles of Hakhamim of Turkey. MS National Library of Israel $8^{0}$ 4445 (Institute of Microfilmed Hebrew Manuscripts, Film B829). (In Hebrew)

[28] Algazi, S. (1718) Ahavat Olam, Contantinople, 155b-156b. (In Hebrew)

[29] Lamdan, R. (1992) The Status of Jewish Women in the Communities of Egypt, Syria, and Palestine in the 16th Century. PhD Thesis, Tel-Aviv University, Tel-Aviv. (In Hebrew)

[30] Ben-Naeh, Y. (2008) Minor Weddings among Jews in the Ottoman Empire. Zemanim, 102, 38-44. (In Hebrew)

[31] Motzki, H. (1996) Child Marriage in Seventeenth-Century Palestine. In: Masud, M.K., Messick, B. and Powers, D.S., Eds., Islamic Legal Interpretation, Harvard University Press, Cambridge, 129-140.

[32] Attias, M. (1946) Marriage Customs in Salonika. Edot, 1, 28-35. (In Hebrew)

[33] Juhasz, E. (1990) Sephardi Jews in the Ottoman Empire: Aspects of Material Culture. The Israel Museum, Jerusalem, 197-217.

[34] Lamdan, R. (1996) Polygamy in the Jewish Society of Palestine and Egypt in the Generations Immediately after the Expulsion from Spain. In: Rozen, M., Porat, D. and Shapira, A., Eds., Daniel Carpi Jubilee Volume, Tel Aviv University, Tel Aviv, 73-89. (In Hebrew)

[35] Lamdan, R. (1996) A Separate People: Jewish Women in Palestine, Syria, and Egypt in the 16th Century. Bitan, Tel Aviv. (In Hebrew)

[36] Bornstein-Makovetsky, L. (1997) Marriage and Divorce in the Jewish Society of Istanbul in the Eighteenth and Nineteenth Centuries. Michael, 14, 139-169. (In Hebrew)

[37] Westreich, E. (1997) "Be Fruitful and Multiply" in Jewish Law in the Ottoman Empire during the Sixteenth Century. Te' udah, 13, 195-240. (In Hebrew)

[38] Karpat, K.H. (2002) The Ottoman Family: Documents Pertaining to Its Size. International Journal of Turkish Studies, 4, 137-145.

[39] Karpat, K.H. (2002) Studies on Ottoman Social and Political History: Selected Articles and Essays. Brill, Leiden, 235-242.

[40] Duben, A. (1985) Turkish Families and Households in Historical Perspective. Journal of Family History, 10, 75-97. https://doi.org/10.1177/036319908501000105

[41] Duben, A. and Behar, C. (1991) Istanbul Households: Marriage, Family and Fertility, 1880-1940. Cambridge University Press, Cambridge.

[42] Rycault, P. (1679) The Present State of the Greek and Armenian Churches. Printed for John Starkey, London, 307.

[43] Algazi, Y. (1982) Responsa, Ed. Ben-Shimon, M., Or haMizrah, Jerusalem, §25, 31 b. (In Hebrew)

[44] Kalai, S. (1599) Mishpetei Shmuel. Venice, 1599, \$90, 90c. (In Hebrew)

[45] Rozen, M. (1996) The Life Cycle and the Significance of Old Age during the Ottoman Period. In: Rozen, M., Porat, D. and Shapira, A., Eds., Daniel Carpi Jubilee 
Volume, Tel Aviv University, Tel Aviv, 122.

[46] Molkho, Y. (1991) Shulhan Gavoha, Salonika, 1780-1784. Vol. 2, Section YorehDe’ah, \$3, 199a. (In Hebrew)

[47] Ben-Naeh, Y. (2005) "Only One Cup of Coffee": Ordinances Concerning Luxuries and Recreation: A Chapter in the Cultural and Social History of the Jewish Community of Jerusalem in the Nineteenth Century. Turcica, 37, 155-185. https://doi.org/10.2143/TURC.37.0.2011703

[48] Rozen, M. (1988) France and the Jews of Egypt: An Anatomy of Relations, 1683-1801. In: Landau, J.L., Ed., The Jews in Ottoman Egypt (1517-1914), Misgav Yerushalayim, Jerusalem, 429-430. (In Hebrew)

[49] Kaufmann, D. (1901) A Written Document Sent from the Holy City to Carpi in 1625. Yerushalayim, 5, 82-83. (In Hebrew)

[50] Faroqhi, S. (2000) Subject of the Sultan: Culture and Daily Life in the Ottoman Empire. I.B. Tauris, London, 104-106.

[51] Modeano, Y.S. (1560) Ne’eman Shmuel. Constantinople, \$57, 70c. (In Hebrew)

[52] HaCohen, E. (1712) ShevetMusar. Constantinople, 1712, 75c. (In Hebrew)

[53] Refael, S. (2004) The Mother-in-Law in the Ladino Folk Song. East and Maghreb, 7, 161-176. (In Hebrew)

[54] Held, M. (2007) "Between the Sea and the River"-A Multi-Layered, Cultural and Literary Analysis of a Sephardic Wedding Song from the Island of Rhodes. El Prezente, 1, 91-122. (In Hebrew)

[55] Held, M. (2015) “Ansina Pueden Dizir Loke Keren” (This Way They Can Say Whatever They Wish): Expressions of Gender in the Personal Narratives of Judeo-Spanish (Ladino) Speaking Storyteller. El Prezente, 8-9, 75-93. (In Hebrew)

[56] Bassan, Y. (1737) Responsa. Constantinople, \$38, 24b. (In Hebrew)

[57] Poremba, D. (1998) A Story from the Thousand and One Nights in Five Versions: The Sexual and Social Discourse in Comparative Context. Jama'a, 2, 21. (In Hebrew)

[58] Zarinebaf-Shahr, F. (1998) Women and the Public Eye in Eighteenth Century Istanbul. In: Hambly, G.R.G., Ed., Women in the Medieval Islamic World: Power, Patronage and Piety, Macmillan, Basingstoke, 307-308.

[59] Ben-Naeh, Y. (2015) Jewish Wills from Salonica: A Source for Social and Cultural History. Hispania Judaica Bulletin, 11, 27-46.

\section{Submit or recommend next manuscript to SCIRP and we will provide best service for you:}

Accepting pre-submission inquiries through Email, Facebook, LinkedIn, Twitter, etc. A wide selection of journals (inclusive of 9 subjects, more than 200 journals)

Providing 24-hour high-quality service

User-friendly online submission system

Fair and swift peer-review system

Efficient typesetting and proofreading procedure

Display of the result of downloads and visits, as well as the number of cited articles

Maximum dissemination of your research work

Submit your manuscript at: http://papersubmission.scirp.org/

Or contact jss@scirp.org 